\title{
Experimentação como interseção entre composição e performance na criação musical: uma experiência de colaboração
}

\section{Experimentation as intersection between composition and performance in musical creation: a collaborative experience}

Heitor Martins Oliveira ${ }^{1}$ Universidade Federal do Tocantins heitormar@gmail.com

Dario Rodrigues Silva ${ }^{2}$ Universidade Federal do Rio Grande do Sul dariorsilva@hotmail.com

Gina Arantxa Arbeláez Hernández ${ }^{3}$ Universidade Federal do Rio Grande do Sul arbelaez.hernandez90@gmail.com

Renan Colombo Simões ${ }^{4}$ Universidade do Estado do Rio Grande do Norte colombo.simoes@gmail.com

Sabrina Souza Gomes ${ }^{5}$ Universidade Federal do Rio Grande do Sul sabrinasouzagomes1993@gmail.com 


\section{Resumo}

O artigo aborda o papel da experimentação na colaboração criativa - composição e performance - do Coletivo N.S.L.O. A investigação é construída a partir dos registros colecionados ao longo do processo criativo e de relatos produzidos pelos(as) próprios(as) integrantes. Assim, a discussão considera as perspectivas particulares de cada um(a), até a consolidação dos produtos musicais. Nesse processo, a experimentação cria um espaço em que compositor e intérpretes atuam juntos de maneira decisiva para o resultado criativo alcançado. Os resultados das experimentações são incorporados à composição, por meio da escrita indeterminada, e à construção da performance, por meio de jogos constituídos por materiais musicais, ações e interações. A colaboração, embora preserve a divisão de papéis, assume caráter horizontal e flexível. A proposta estética abarca os aspectos de teatralidade e jogo como resultado da dinâmica entre escrita indeterminada e performance.

Palavras-chave: Criação musical; colaboração; indeterminação; experimentação; processo criativo.

\section{Abstract}

The article discusses the role of experimentation in the creative collaboration - composition and performance - of the group Coletivo N.S.L.O. The investigation builds on records collected during the creative process and reports produced by the members themselves. Thus, the discussion considers the particular perspectives of each one, until the consolidation of the musical products. In this process, experimentation creates a space in which the composer and performers act together in a decisive way for the creative result achieved. The results of the experiments are incorporated into the composition, through indeterminacy, and performance preparation, through games, consisting of musical materials, actions and interactions. Collaboration, while preserving the division of roles, is horizontal and flexible. The aesthetic proposal encompasses the aspects of theatricality and play, as a result of the dynamics between indeterminate notation and performance.

Keywords: Musical creation; collaboration; indeterminacy; experimentation; creative process.

\footnotetext{
1 Professor adjunto da Universidade Federal do Tocantins. Possui bacharelado em Música (Regência) e licenciatura em Educação Artística pela Universidade de Brasília (2002 e 2006), mestrado em Música (Composição) - Texas State University - San Marcos (EUA) (2004), título reconhecido no Brasil pela Universidade Federal de Goiás (2008), e doutorado em Música (Composição) pela Universidade Federal do Rio Grande do Sul (2018). 2 Doutor em Música - Práticas Interpretativas, piano - pela Universidade Federal do Rio Grande do Sul (UFRGS), bolsista CAPES sob a orientação da Prof. ${ }^{a}$ Dr. ${ }^{a}$ Catarina Leite Domenici. Em 2015, graduou-se Mestre em Música, bolsista CNPq na mesma instituição (UFRGS), sob a orientação da Prof. ${ }^{a}$ Dr. ${ }^{a}$ Catarina L. Domenicci. Em 2013, graduou-se Bacharel em Música Instrumento: Piano na Universidade de São Paulo (USP), campus Ribeirão Preto, sob a orientação do Prof. Dr. Fernando Crespo Corvisier.

3 Possui graduação em Interpretación Musical pelo Instituto Departamental de Bellas Artes - Cali (2013). Atualmente é Doutoranda no PPG em Música da UFRGS e flautista da Orquestra de Sopros de Novo Hamburgo. Tem experiência na área de Artes, com ênfase em Performance Musical e Educação.

$4 \quad$ Professor Adjunto II da Universidade do Estado do Rio Grande do Norte (UERN), Doutor e Mestre em Música (Práticas Interpretativas - Violão) pela Universidade Federal do Rio Grande do Sul (UFRGS), orientado por Daniel Wolff e Leonardo Winter, bacharel em Música (Habilitação - Violão) pela Faculdade de Música do Espírito Santo (FAMES), orientado por Fabiano Mayer, e especialista em Arte e Educação pelo Instituto Superior de Educação e Cultura Ulysses Boyd.

5 Sabrina Souza é Mestre em Música (Práticas Interpretativas) pela Universidade Federal do Rio Grande do Sul (UFRGS); Bacharel em Música com habilitação em Violão pela Faculdade de Música do Espírito Santo ?Maurício de Oliveira? (FAMES), e atua como professora substituta na Universidade Federal do Rio Grande do Norte (UFRN) nos cursos de Bacharelado e Técnico em Violão.
} 
A autoria deste artigo é de cinco artistas-pesquisadores(as): um compositor (Heitor Oliveira), uma flautista (Gina Arantxa), um pianista (Dario Rodrigues Silva) e dois violonistas (Renan Simões e Sabrina Souza). Compartilhamos o interesse em criação musical colaborativa e em certas potencialidades estéticas da situação de performance musi$\mathrm{cal}^{6}$, tais como a interação com o público e o reconhecimento dos elementos visuais e gestuais na criação de peças musicais.

Denominamos nosso trabalho colaborativo de Coletivo N.S.L.O (Norte, Sul, Leste, Oeste) em referência à diversidade de percursos geográficos em nossas trajetórias de vida e de atuação artística e acadêmica. $O$ projeto inicial ${ }^{7}$ do grupo consiste na realização de cinco encontros, distribuídos em um período de vários meses, ao longo dos quais criamos um repertório original baseado nos interesses e capacidades individuais, na colaboração e em experiências compartilhadas ${ }^{8}$.

A experimentação mediou as práticas do Coletivo N.S.L.O, constituindo-se como interseção entre as esferas de atuação criativa de compositor e performers e como espaço para delimitação de possibilidades técnicas e expressivas para construção de seu repertório. As peças construídas coletivamente a partir desse processo de experimentação abarcam diferentes tipos e graus de escrita indeterminada e jogo durante a performance. Nesse contexto, jogo remete a um modo de construção da performance que aborda as aberturas da escrita indeterminada, a necessidade de interação entre os(as) agentes da performance (incluindo assistentes) e a coexistência do aspecto sonoro com aspectos gestuais, verbais e visuais. O Quadro 1, a seguir, apresenta uma listagem das peças com sínteses dos modos de indeterminação (escrita) e jogos (performance) utilizados em cada uma. Neste texto, abordaremos, de maneira detalhada, o trabalho com experimentação e indeterminação/jogo nas duas primeiras peças do repertório apresentado no Quadro 1.

\footnotetext{
6 Considera-se a concretude e multissensorialidade da situação de performance musical e as implicações dessas características para a criação e recepção musical. 0 que se pretende como proposta criativa é "abordar, a partir de critérios e procedimentos composicionais, o espaço e as convenções da situação de performance de música de concerto, as visualidades e gestualidades da execução instrumental e vocal, visando sua integração em um percurso musical-cênico" (OLIVEIRA, 2018, p.8).

7 Projeto contemplado no Programa Rumos Itaú Cultural 2017-2018.

8 Até a escrita do artigo, foram realizadas as quatro primeiras etapas do projeto: Porto Alegre/RS (novembro de 2018), Mossoró/RN (março de 2019), Ribeirão Preto/SP (julho de 2019) e Cali/Colômbia (fevereiro de 2020). Completando o projeto, teremos a quinta etapa em Palmas/TO (realização suspensa devido à pandemia da Covid-19), quando também será realizada a gravação do álbum do grupo. As cidades escolhidas correspondem a locais de origem, formação ou atuação profissional dos músicos. Cada etapa inclui atividades de criação colaborativa do grupo e atividades abertas ao público, como masterclasses e concertos.
} 


\begin{tabular}{|c|c|c|}
\hline Peças & Formação & Indeterminação/Jogo \\
\hline $\begin{array}{l}\text { Tudo é perdido quando o desejo } \\
\text { fica repartido }\end{array}$ & $\begin{array}{l}\text { Dois violões, assistentes e difu- } \\
\text { são sonora }\end{array}$ & $\begin{array}{l}\text { Dois momentos da peça são } \\
\text { escritos por meio de instruções } \\
\text { verbais }\end{array}$ \\
\hline $\begin{array}{l}\text { Novos sururus e quiprocós de } \\
\text { um convescote chumbrega }\end{array}$ & $\begin{array}{l}\text { Flauta, piano, assistentes e difu- } \\
\text { são sonora }\end{array}$ & $\begin{array}{l}\text { Assistentes realizam sorteios } \\
\text { para disponibilizar módulos mu- } \\
\text { sicais aos intérpretes de maneira } \\
\text { aleatória durante toda a perfor- } \\
\text { mance }\end{array}$ \\
\hline charla \#1 & Piano e áudio em mídia fixa & $\begin{array}{l}\text { Indicação de tocar um trecho } \\
\text { musical e comentar enquanto } \\
\text { toca; este trecho pode ser repe- } \\
\text { tido ou ter sua conclusão adiada } \\
\text { até a seção seguinte }\end{array}$ \\
\hline charla \#2 & Flauta e vídeo em mídia fixa & $\begin{array}{l}\text { Sobreposição aleatória entre } \\
\text { execução ao vivo e difusão au- } \\
\text { diovisual }\end{array}$ \\
\hline charla \#3 & Violão (2) e vídeo em mídia fixa & $\begin{array}{l}\text { Indicação de tocar um trecho } \\
\text { musical e comentar enquanto } \\
\text { toca; este trecho pode ser repe- } \\
\text { tido ou ter sua conclusão adiada } \\
\text { até a seção seguinte }\end{array}$ \\
\hline charla \#4 & Flauta, piano e dois violões & $\begin{array}{l}\text { Indicação de tocar um trecho } \\
\text { musical e comentar enquanto } \\
\text { toca; este trecho pode ser repe- } \\
\text { tido ou ter sua conclusão adiada } \\
\text { até a seção seguinte }\end{array}$ \\
\hline charlatório & $\begin{array}{l}\text { Piano e violão (1), com amplifi- } \\
\text { cação e processamento de áudio }\end{array}$ & $\begin{array}{l}\text { Jogo coletivo com trechos e } \\
\text { motivos das charlas }\end{array}$ \\
\hline The meme loop & $\begin{array}{l}\text { Piano e violão (1), com amplifi- } \\
\text { cação e processamento de áudio }\end{array}$ & $\begin{array}{l}\text { Jogo de livre alternância entre } \\
\text { células musicais escritas }\end{array}$ \\
\hline El viejo de bien & $\begin{array}{l}\text { Flauta e violão (2), com difusão } \\
\text { sonora, iluminação amplificação } \\
\text { e processamento de áudio }\end{array}$ & $\begin{array}{l}\text { Jogo de livre alternância entre } \\
\text { células musicais escritas }\end{array}$ \\
\hline Rosa dos ventos & $\begin{array}{l}\text { Flauta, piano e dois violões, com } \\
\text { difusão sonora, projeção de } \\
\text { vídeo, iluminação, amplificação } \\
\text { e processamento de áudio }\end{array}$ & - \\
\hline
\end{tabular}

Quadro 1: Lista do repertório original do Coletivo N.S.L.O (ordem de estreia) com indicação da formação e dos tipos de indeterminação/jogo adotados em cada peça

O recorte adotado para este trabalho tem como foco o processo criativo, voltando o seu interesse para a investigação de uma maneira de compor, e não somente da escritura concretizada (DONIN, 2010). Pressupõe, portanto, a relevância da discussão de um enfoque composicional particular, na medida em que a elucidação dos diálogos do compositor com a tradição e com as condições concretas de realização artística contribui para a compreensão da diversidade presente no cenário da criação musical na atualidade (DONIN, 2012; LIMA, 2012).

Nessa perspectiva, propomos, inicialmente, a delimitação das noções de colaboração e indeterminação relevantes para nossas práticas de criação musical para, em 
seguida, discorrer sobre o seu desenvolvimento em nossos processos criativos. Nas revisões de literatura e discussões, adotamos a primeira pessoa do plural, refletindo um consenso construído a partir de debates e do estudo de referências, bem como as relações que propusemos entre nossa experiência e o conhecimento sedimentado nos campos acadêmicos da composição e performance musical. Nas seções relativas aos nossos processos criativos, abrimos espaço para a escrita em primeira pessoa do singular, dando voz a cada componente do grupo, em diálogo com a voz coletiva, que discute essas narrativas e reflexões individuais. Essa opção nos parece mais coerente com a nossa vivência e com a explicitação de nossa escolha de considerar o processo de criação artística como parte da nossa metodologia de pesquisa (FORTIN; GOSSELIN, 2014). Assim, as descrições e considerações apresentadas valem-se de registros dos processos de composição e construção de performance (anotações, manuscritos, gravações, postagens em redes sociais e blog do projeto ${ }^{9}$ ) e de reflexões empreendidas a posteriori a partir da memória e do confronto com os registros disponíveis.

\section{Colaboração entre compositores e intérpretes: conceitos e tendências}

Relatos de colaborações entre compositores e intérpretes não são raros na história da música ocidental de concerto. São conhecidas parcerias dessa natureza nos diversos períodos: entre Johann Sebastian Bach (1685-1750) e o flautista Pierre Gabriel-Buffardin (1689-1768); entre Wolfgang Amadeus Mozart (1756-1791) e o também flautista e compositor Johann Baptist Wendling (1723-1797); entre Johannes Brahms (1833-1897) e Robert Schumann (1810-1856) com o violinista húngaro Joseph Joachim (1831-1907). Dentre casos mais recentes, figuram as colaborações entre Anton Webern (1883-1945) e o pianista austríaco Peter Stadlen (1910-1996), Edgar Varèse (1883-1965) e o flautista francês Georges Barrère (1876-1944), Olivier Messiaen (1908-1992) e a pianista e compositora francesa Yvonne Loriod (1924-2010) e as parcerias que Luciano Berio (1925-2003) desenvolveu com vários intérpretes, como Cathy Berberian (1925-1983), Vinko Globokar (1934), Severino Gazzelloni (1919-1992) e Stuart Dempster (1936), para a criação de sua série Sequenze (1958-2004).

Apesar destes vários relatos, a insuficiência ou até mesmo a ausência de documentações sobre estas interações dificultam as investigações sobre os tipos de relações entre as partes envolvidas, os papéis desempenhados por cada uma das partes ou as influências que uma parte exerceu sobre a outra. Investigações e discussões mais aprofundadas sobre os diferentes tipos de interações e as relações nelas implícitas começam a despontar nos ambientes de pesquisa à medida que os registros e documentações dos processos interativos estudados são tratados com critérios mais cuidadosos, possibilitando cruzamentos mais ricos de informações sobre as dinâmicas das relações (cf. SILVA, 2019, p.28).

\footnotetext{
9 Descrições e reflexões sobre as preparações de performance das obras, processo de escrita, ensaios e outros tipos de relatos podem ser acessados no blog do Coletivo N.S.L.O: http://coletivonslo.blogspot.com/. 0 armazenamento e compartilhamento desses relatos também são pensados para auxiliar nossas pesquisas, como uma maneira de registrarmos as múltiplas perspectivas dos(as) integrantes do grupo.
} 
Há de considerarmos também que as pesquisas que tratam especificamente sobre interações entre compositores(as) e intérpretes são relativamente recentes na literatura acadêmica. No cenário da pesquisa no Brasil, os primeiros trabalhos que abordam o tema surgem a partir do final da década de 1990, com artistas-pesquisadores(as) como Borém (1998, 1999), Ray (2001) e Tokeshi e Copetti (2004). Nos anos seguintes, especialmente a partir de 2010, é possível notarmos um aumento significativo no volume e frequência de publicações sobre interações entre intérpretes e compositores(as) (e.g., DOMENICI, 2010, 2011, 2013; CARDASSI, 2011; ROSA; TOFFOLO, 2011; ISHIZAKI, 2013; RADICCHI, 2013; SILVA, 2015, 2019; GOMES, 2017).

Considerando a literatura acadêmica sobre interações entre compositores(as) e intérpretes e a variedade de temas que esses trabalhos abordam, podemos identificar tópicos que figuram entre os mais frequentes e outros que despontam como tendências (cf. SILVA, 2019, p.15). Discussões sobre o idiomatismo, por exemplo, são recorrentes desde os primeiros trabalhos até os mais recentes. Nestes trabalhos, destacam-se benefícios como: a diminuição da disparidade entre performance e escrita a partir da interação entre compositores(as) e intérpretes; a importância do contato com o(a) intérprete para que o(a) compositor(a) tenha conhecimento dos avanços técnicos do instrumento; as consequências positivas deste processo, como as divulgações de novas obras de compositores(as) contemporâneos(as) e a ampliação do repertório dos instrumentos. Igualmente frequentes são os trabalhos que tratam sobre o desenvolvimento de técnicas expandidas, apontando ganhos como a ampliação do métier técnico e expressivo dos(as) intérpretes, a criação de novos grafismos por parte do(a) compositor(a), a expansão das possibilidades do instrumento e o contato do(a) compositor(a) com novas ideias a partir de demonstrações do(a) intérprete ao instrumento. Trabalhos que focam a documentação da prática de performance e/ou o relato de processos de construção performática nas perspectivas dos(as) intérpretes, em conjunto com os(as) compositores(as), são igualmente recorrentes.

A partir de 2010, nota-se uma tendência cada vez mais proeminente de trabalhos sobre interseções de duas ou mais áreas artísticas (e.g., música e teatro; música e dança; música, cinema e artes plásticas) e/ou que abarcam as possibilidades advindas de ferramentas tecnológicas e recursos multimídias. É no âmbito dessas tendências que podemos situar a proposta artística do Coletivo N.S.L.O. Entendendo a natureza do nosso trabalho, podemos explorar o tipo de interação que desenvolvemos e quais aspectos estão relacionados a esse tipo observado.

O Coletivo N.S.L.O nasce da amálgama de interesses mútuos do compositor e intérpretes a partir do desejo de ampliação de nossas habilidades criativas, expressivas, comunicativas e da escrita para nossos instrumentos. Nossas obras envolvem projeções de vídeos e imagens, difusões sonoras, iluminações, teatralidades na performance, intérpretes em cenas, interações com o público, preparações de ambientes, objetos e percursos. Além disso, desenvolvemos discussões sobre o tipo de público com o qual lidamos, as características de cada um dos locais em que nos apresentamos e a necessidade de nos ajustarmos às adversidades, visando assim uma melhor gestação de nossos 
modos de apresentação e interação com o público. São demandas que caracterizam a dinâmica de trabalho do grupo, estimulando relações de naturezas interdependentes e sinergéticas entre os(as) integrantes.

Há aqui ressonâncias com o relato que Domenici compartilha em seu artigo "It takes two to tango: a prática colaborativa na música contemporânea". A autora fundamenta a interdependência entre as partes no conceito de arquitetônica de Mikhail Bakhtin (1895-1975). Esse conceito considera

[...] a simultaneidade entre o eu e o outro na participação do evento, bem como a oposição epistemológica entre esses. Essas duas forças, cada uma com o seu próprio sistema de valores, estão em estado de constante tensão dialógica, no qual uma não pode ser compreendida sem a outra. O lugar situado que cada um desses sujeitos ocupa na relação dá a ambos uma percepção privilegiada tanto do outro quanto da obra, de maneira que um percebe coisas que não são disponíveis ao outro e vice-versa, o que Bakhtin denomina de "excesso de visão". (DOMENICl, 2013, p.10-11).

Os "excessos de visões" mostram-se fundamentais para compreendermos as relações e interdependências entre os(as) integrantes e o modo de trabalho do Coletivo N.S.L.O: nossos encontros presenciais são pontuais, com duração média de uma semana, e, entre uma etapa e outra, há longos períodos de afastamento entre os(as) integrantes. Isso faz com que valorizemos o compartilhamento e o acolhimento desses excessos para desenvolvermos a coesão estética, estilística e identitária do grupo. Assim, o trabalho é caracterizado pela presença e participação de todo o grupo em todas as experimentações e montagens das peças, ocasiões nas quais atuamos como assistentes uns dos outros. E, ainda, por constantes diálogos - não só presencialmente, mas também em ambientes virtuais (aplicativos, e-mails e redes sociais) - após ensaios, apresentações e etapas de atividades.

De certo modo, conhecer essas circunstâncias é, também, conhecer o(a) outro(a), o que ressalta a importância das afinidades entre os(as) integrantes do grupo. Como observado por Ishizaki, "[...] colaborações tendem a funcionar melhor quando os colaboradores possuem afinidades estéticas suficientemente próximas e algum nível de flexibilidade em relação a experimentalismos, bem como alguma vivência musical em comum" (ISHIZAKI; MACHADO, 2013, p.101). Em alguns casos, a percepção das afinidades e dos interesses musicais entre as partes pode também auxiliar no delineamento de possíveis diretrizes que estarão em jogo durante a colaboração (RADICCHI, 2014, p.202).

O modo como as extrapolações de visões, interdependências, sinergias e afinidades atuam entre os(as) integrantes do grupo concede um significativo grau de flexibilidade para nossas relações interpessoais. Aqui, entende-se por flexibilidade os momentos em que "[...] um campo - performance ou composição - interferiu no outro, ou ainda, o quanto um agente de um campo decidiu ou motivou questionamentos ou alteração no outro" (SILVA, 2019, p.151). Certamente, temos de considerar que flexibilizações diferentes podem expressar variados níveis de intensidades.

No trabalho desenvolvido com a compositora sueca Love Mangs (1966), por exemplo, Stefan Östersjö observa um tipo raro de colaboração que ele denomina de "cola- 
boração totalmente integrada" - fully integrative collaboration -, definida pelo próprio como sendo aquela que ocorre em ambientes mais imersivos e que preservam processos abertos, permitindo inclusive as ocorrências de sobreposições de funções (ÖSTERSJÖ, 2008, p.196). As sobreposições citadas pelo autor são dadas pelos momentos em que há borramentos entre as fronteiras que dividem os papéis de ambos, no caso, composição e performance:

Em diferentes fases do nosso trabalho, ambos nos encontramos escrevendo música; trabalhando analiticamente em tempo não real; preparando material para a peça; tocando violão - ao produzir material para a parte acústica e ao interagir com as eletrônicas no processo de definição da parte eletrônica. Por essa razão, foi totalmente possível para nós abordarmos a colaboração em um modo integrativo, adaptando nossas ferramentas artísticas ao trabalho do outro $^{10}$. (ÖSTERSJÖ, 2018, p.196, tradução nossa).

Ishizaki também observa sobreposições no decorrer da colaboração realizada com o compositor e violonista Marco Antônio Machado, que resultou na obra Arcontes:

\begin{abstract}
Nesta reflexão, qualquer categorização hierárquica das funções perde completamente seu sentido, já que surgem, latentes ao processo criativo, as seguintes questões: qual é efetivamente a função do compositor ao trazer o intérprete para coletar materiais? Não estaria o compositor atuando também como intérprete ao "ler" e formalizar os materiais então sugeridos? E ainda: não estaria o compositor, atuando na manipulação das amostras e disparos nos patches junto ao intérprete, atuando literalmente como um performer da própria obra? Questões de ordem similar podem ser elaboradas em relação ao intérprete: não teria ele créditos como coautor (ou ao menos colaborador) da obra ao contribuir de maneira tão decisiva em relação aos materiais que estruturam sua sintaxe? Não seria o intérprete igualmente responsável pelo discurso poético e estético da obra, ao ter participado ativamente dos processos de criação da mesma? Não seria a figura do intérprete um elemento altamente determinante, ao refletir suas escolhas e sua intelectualidade sobre os materiais que o compositor manipula (ou interpreta)? (ISHIZAKI; MACHADO, 2013, p.99-100).
\end{abstract}

As reflexões dos autores sobre a natureza da flexibilidade percebida no trabalho estimularam as críticas sobre as funções desempenhadas por ambos e as discussões sobre a autoria da obra.

\title{
Indeterminação e composição musical: marcos e referências
}

Assim como as colaborações entre compositores(as) e intérpretes, os distintos graus de indeterminação da escrita e as relações entre oralidade e notação são também aspectos recorrentes na história da música ocidental de concerto, o que pode ser percebido tanto nas práticas interpretativas de determinados períodos - por exemplo,

\footnotetext{
10 Original: "[...] In different phases of our work we were both found to be writing music; working analytically in non-real time; preparing material for the piece; playing guitar - when producing material for the acoustic part and when interacting with the electronics in the process of defining the electronic part. For this reason it was fully possible for us to approach the collaboration in an integrative mode, adapting our artistic tools to the work of the other" (ÖSTERSJÖ, 2008, p.196).
} 
a realização de baixos cifrados no Barroco - quanto em relatos da proficiência improvisadora de compositores/intérpretes, como Johann Sebastian Bach (1685-1750), Ludwig van Beethoven (1770-1827), Frédéric Chopin (1810-1849), Olivier Messiaen (1908-1992), entre outros.

No que se refere aos processos criativos da música de concerto atual, a noção de indeterminação, introduzida na década de 1950 por compositores ligados ao experimentalismo norte-americano - notadamente John Cage (1912-1992) - e à vanguarda europeia - notadamente Pierre Boulez (1925-2016) e Karlheinz Stockhausen (1928-2007) -, constitui-se como referência central para as práticas de composição atuais que ampliam o campo de decisões dos(as) intérpretes. Assim, a noção de indeterminação abarca uma ampla gama de possibilidades composicionais e performativas, refletindo diferentes interesses estéticos e soluções técnicas de notação e delimitação de materiais sonoros, estruturas, gestos físicos ou atitudes para a construção de performances musicais. Ao revisar um recorte restrito da literatura sobre o tema, interessa-nos particularmente refletir sobre as intenções expressivas, escolhas poéticas e implicações formais da indeterminação.

Como representante do experimentalismo norte-americano, John Cage notabilizou-se pela sua abordagem da indeterminação com ênfase no acaso, fazendo uso de notação gráfica, como em TV Köln (1958) ${ }^{11}$, uma peça curta para piano, prevendo execução na parte interna da construção do instrumento, na parte externa, no teclado e com uso de um ruído auxiliar de livre escolha. A realização de partituras escritas em notação gráfica implica uma abertura para a performance, que coloca em evidência a colaboração de Cage com intérpretes, especialmente David Tudor (1926-1996), que mantinha a prática de escrever suas próprias realizações das partituras indeterminadas ${ }^{12}$. A escrita indeterminada de TV Köln é ilustrativa da notação gráfica de Cage e delimita alguns elementos, como o campo de escolhas sonoras, a duração relativa e ordem de apresentação dos sons, enquanto deixa outros em aberto, principalmente as escolhas específicas de alturas e sonoridades e a duração precisa das ações.

Confrontados com as propostas estéticas e com os resultados sonoros da indeterminação do experimentalismo norte-americano ${ }^{13}$, compositores europeus ligados ao serialismo integral foram compelidos a explorar suas próprias abordagens à indeterminação. A Sonata para piano no 3, de Pierre Boulez (2014), é um marco desse momento. O tipo de escrita indeterminada adotada nesse contexto refere-se à forma. A partitura é escrita em partes intercambiáveis, cabendo ao intérprete construir seu trajeto pelos múltiplos materiais fornecidos pelo compositor. A escrita é precisa quanto às alturas, ritmos e demais elementos pontuais, mas indeterminada quanto à ordem de execução. As concepções estruturais de Boulez fundamentam sua defesa de que o aspecto de acaso na criação musical deve ficar restrito a esse tipo de escolha facultada ao intérprete.

\footnotetext{
11 Partitura: Cage (1960). Vídeo: CAGE: TV Koln (Elif Onal, piano). Ankara: [s. n.], 22 nov. 2012.1 vídeo (3 min). Publicado pelo canal Bilkent Composition. Disponível em: https://youtu.be/w-WM30H5D4s. Acesso em: Jul. 2020.

12 Para uma discussão detalhada da relação criativa entre os dois artistas, ver Iddon (2013).

13 Além de Cage, o trabalho do compositor Earle Brown (1926-2002) também teve repercussão em círculos europeus, notadamente para o compositor italiano Bruno Maderna (1920-1973) (MATHON, 2013).
} 
A abordagem talvez mais radical à escrita indeterminada viria com a música intuitiva de Karlheinz Stockhausen, epitomizada em Aus den sieben Tagen (1968). Aqui, a partitura consiste em poemas com sugestões poéticas para criação sonora. O posicionamento estético de Stockhausen pretende instigar uma prática de criação sonora destituída de referências estilísticas. Essa abordagem leva a indeterminação ao limite, apontado o caminho para as práticas de improvisação livre ${ }^{14}$, improvisação experimental ${ }^{15}$ e improvisação generativa ${ }^{16}$.

No contexto brasileiro, um desenvolvimento mais recente do trabalho composicional com notação indeterminada está ligado à atuação de Hans Joachim Koellreutter (1915-2005). O compositor teuto-brasileiro descreve da seguinte maneira seu posicionamento estético:

Na estética relativista do impreciso e paradoxal, as interações de sons e ocorrências musicais são representadas em diagramas temporais que permitem estruturar os lapsos de tempo em que ocorre a música, de maneira englobante, resultando uma composição em que sons e silêncios podem ser interpretados como positivos e negativos como sucede na imagem fotográfica. Resulta uma espécie de "renda", um tecido de sons e contexturas, que formam desenhos transluzindo o fundo, isto é, o silêncio estruturado. (KOELLREUTTER, 1990, s.p.).

Koellreutter (1990) propõe, portanto, uma notação gráfica não linear que ele mesmo define como uma proposta a meio caminho entre música de concerto e música improvisada. Suas partituras funcionam simultaneamente como provocações para o desenvolvimento de potencialidades criativas e molduras estruturantes para performances individuais ou coletivas.

Puig (2013) desenvolve sua própria abordagem composicional a partir da noção de composição planimétrica de Koellreutter. Voltando sua atenção às implicações da notação indeterminada, destaca que vários de seus aspectos $₫$ figuras, símbolos, textos, suportes - podem conter mensagens ou servir de contextualização para a interpretação de outros aspectos da própria notação. Considerando essa complexidade, analisa sua prática criativa a partir da teoria sistêmica e discorre sobre o processo criativo que denomina composição com improvisação:

A identidade da obra está em relação direta com a qualidade das inter-relações dentro do processo que envolve os músicos e a partitura. Sempre há um risco de que a obra desmorone, que ela não se sustente por si mesma, por ser o produto de inter-relações complexas que começam muito antes de uma apresentação e se estende por longos períodos de tempo. Nele, o intérprete irá criar a sua própria obra, inscrevê-la em seu corpo (em seus gestos, nos resultados sonoros que obtém do seu instrumento, na sua memória muscular e afetiva) e talvez até mesmo em outros tipos de notação. Durante os ensaios, irá dedicar-se a procurar

\footnotetext{
14 Devido às características da colaboração estabelecida no contexto do Coletivo N.S.L.O, não discutimos neste texto a improvisação livre e o uso ou desenvolvimento de tecnologias interativas. Sobre essas questões, remetemos o leitor ao importante trabalho de Costa (2016).

15 Sobre as estratégias para desenvolvimento de práticas de improvisação não idiomática experimental, remetemos o leitor ao trabalho de Nesrala (2018).

16 Termo que remete mais especificamente às propostas de Alain Savouret (cf. CANONNE, 2010).
} 
bons resultados e soluções criativas. No momento da performance, irá utilizar o máximo do seu potencial para tentar recriar o melhor desse processo. Este risco não deve ser encarado como improdutivo, mas como atuante no processo e em grande parte responsável pela sua reconstrução. É dele, dessa possibilidade de que a obra não se faça, que nasce o maior impulso para que ela venha a existir de fato. (PUIG, 2013, s.p.)

Puig defende, portanto, o risco produtivo em sua abordagem de composição com improvisação, atribuindo a esse risco a motivação para o desenvolvimento da performance, a qual é responsável por transformar as ideias contidas na partitura em uma obra musical de fato. $O$ aspecto corporal e concreto dessa construção da performance é visto como parte integrante do processo, abarcando inter-relações complexas.

$\mathrm{Na}$ experiência do Coletivo N.S.L.O, identificamos uma manifestação específica desse risco produtivo. Os tipos de indeterminação utilizados em nossas partituras/roteiros enfatizam as interações entre intérpretes e destes com a assistência, criando situações em que a responsabilidade pela continuidade e sustentação de interesse em uma performance é compartilhada pelos(as) diferentes agentes. No mais das vezes, a indeterminação surge como elemento em uma trama composicional com outros elementos e condicionantes.

Em outra interessante contribuição recente ao tema da relação entre composição e indeterminação, Moraes (2015) discute sua própria prática por meio de uma analogia entre o processo de criação do áudio dinâmico para jogos eletrônicos e a indeterminação na composição escrita. Dentro das práticas desenvolvidas na indústria de jogos eletrônicos, o áudio dinâmico engloba os conceitos de áudio interativo e adaptativo. 0 áudio interativo refere-se às mudanças de som de acordo com ações do jogador - por exemplo, som de pulo gerado pelo apertar de botão - e áudio adaptativo reagindo a estados de jogo, como mudanças de andamento (MORAES, 2015, p.730). Na obra Ludum, Moraes desenvolve essa analogia, atribuindo ao regente um papel análogo ao do jogador e aos intérpretes um papel análogo ao dos algoritmos de áudio dos jogos eletrônicos (p.731). Essa interatividade implica, como nos jogos eletrônicos, a quebra de linearidade do discurso musical, propiciando uma organização formal com ramificações em várias direções (p.732).

A analogia proposta por Moraes (2015) coloca em evidência o aspecto lúdico dos processos criativos mediados pela escrita indeterminada, ludicidade que ressoa com as práticas do Coletivo N.S.L.O. Ao dialogar sobre o roteiro das peças, costumamos designar seções indeterminadas como jogos e privilegiar o estabelecimento de dinâmicas interativas, envolvendo não apenas as sonoridades, mas também dimensões gestuais, verbais e visuais da performance.

Assim, a prática do Coletivo N.S.L.O dialoga com tradições estabelecidas e experimentações documentadas no campo da criação musical, e ainda com práticas construídas no campo da criação cênico-musical, particularmente ligadas ao que um grupo de pesquisadores recentemente denominou Teatro Composto (REBSTOCK, 2012a; RO- 
ESNER, 2012) ${ }^{17}$. Aqui, a experimentação refere-se principalmente ao processo criativo, mediando colaborações musicais e multimidiáticas. Trabalhando com seu Atelier Théâtre et Musique (Atem) no período de 1977 a 1997, Georges Aperghis (n. 1945) adotava a prática de levar trechos musicais para ensaios e conduzir experimentações com os músicos e outros artistas, realizando ações com ou sem implicação sonora em determinadas disposições espaciais e contextos visuais (REBSTOCK, 2012b). Nesse processo, a composição, tanto em seu aspecto puramente musical quanto em sua amplitude cênica, é concluída nos ensaios, mediada pelas experimentações cênico-musicais guiadas.

A proposta composicional de Heitor, compositor do Coletivo N.S.L.O, dialoga com o interesse na teatralidade da performance musical, evidente em parte do trabalho de compositores como o próprio Aperghis, Luciano Berio (1925-2003), Gilberto Mendes (1922-2016) e Mauricio Kagel (1931-2008). Esse interesse estético motiva a exploração de gestualidades, visualidades e vocalizações, geradoras de intermitências ficcionais, ou seja, de deslizamentos de sentido entre performance - apresentação de ações com e sem implicação sonora - e representação - releitura ficcional dos elementos apresentados no espaço cênico ${ }^{18}$. Assim, essa proposta composicional busca inserir as ações vinculadas ou não à execução instrumental (vocalizações, gestos físicos) e todos os elementos da performance em um jogo cênico com suas próprias peculiaridades, profundamente pautado pelas idiossincrasias da execução musical, ao mesmo tempo que admite possibilidades de significação ficcional.

A seguir, alternando a voz de cada componente com uma voz coletiva que reflete nosso consenso, apresentamos narrativas e reflexões individuais sobre diferentes etapas e aspectos de nossa prática e sua discussão a partir das noções de colaboração e indeterminação/jogo aqui apontadas.

\footnotetext{
17 A noção de teatro composto é uma moldura teórica para abordar processos criativos nos quais modelos e técnicas composicionais musicais são aplicados a materiais e ações teatrais (ROESNER, 2012).

18 Essa abordagem composicional é apresentada e discutida pelo compositor em sua tese de doutorado (OLIVEIRA, 2018).
} 


\section{Oficina de criação colaborativa}

Na primeira etapa do projeto do Coletivo N.S.L.O, em Porto Alegre (RS), realizamos uma oficina de criação colaborativa, na qual o compositor apresentou, aos(às) intérpretes, propostas para as peças específicas a serem criadas ao longo das etapas seguintes, instaurando um diálogo sobre questões técnicas e expressivas.

\section{COMPOSITOR (Heitor)}

Cheguei ao primeiro encontro do Coletivo N.S.L.O com a responsabilidade de compartilhar com o grupo uma proposta idealizada inicialmente por mim, cuja intenção era catalisar a participação efetiva de todos(as). Para tanto, apresentei a eles(as) uma série de planos, questionamentos e provocações. Pressupunha que, dada a natureza do projeto, seria mais produtivo ter algumas metas e diretrizes a partir das quais as atividades pudessem avançar.

Apresentei um cronograma para criação de peças ao longo das etapas do projeto, explorando as possibilidades de formações de solos, duos e quartetos ${ }^{19}$. Além da proposta de formação de cada peça, trouxe também algumas propostas mais específicas, principalmente títulos, ideias expressivas e estruturais, pertinentes a uma estética composicional pessoal voltada para a teatralidade da performance musical.

Apesar desse planejamento relativamente detalhado, cheguei ao primeiro encontro sem um esboço escrito de ideias musicais para serem experimentadas pelos(as) intérpretes em seus instrumentos. Entendia que, para estar pronto para selecionar e desenvolver materiais musicais para as peças, necessitava de diálogo e experimentações práticas, que procurei fomentar por meio de questões que viriam a ressoar nos meses seguintes de nossas interações.

Assim, apresentei ao coletivo questões sobre o projeto, a construção de nossa proposta artística, a identidade de cada um(a) de nós como músicos/musicistas e as possibilidades de escrita. As questões fomentaram o diálogo e, em alguns casos, experimentações. Esse foi o caso da discussão sobre indeterminação na escrita, que culminou em experimentações relevantes para o processo criativo de Tudo é perdido quando o desejo fica repartido (para dois violões, assistência e difusão sonora), que designaremos no texto como ...repartido, e Novos sururus e quiprocós de um convescote chumbrega (para flauta, piano, assistência e difusão sonora), que designaremos como ...sururus....

Por se tratar de duos, as minhas provocações visavam explorar, principalmente, as possibilidades de simultaneidade sonora e de organização do espaço de performance. Para ...repartido, propus a referência literária do texto dramático Macbeth, de William Shakespeare (1564-1616). A intenção expressiva que eu procurava transmitir era a de criar uma performance musical na qual as relações entre um casal de instrumentistas evocam situações dramáticas entre as duas personagens centrais da tragédia shakespeariana. As experimentações foram realizadas a partir de diferentes posicionamentos dos

19 A lista apresentada nesta etapa como meta já era praticamente idêntica ao repertório efetivamente produzido ao longo do projeto, conforme se vê no Quadro 1. 
instrumentistas: frente a frente, de costas, de lado, próximos, distantes. Para ...sururus..., as experimentações foram realizadas a partir de sugestões sobre o material musical: cada instrumentista deveria improvisar repetindo ideias musicais estáticas (que eu chamava de platôs), entre as quais deveria propor transições (que eu chamava de percursos), sempre reagindo às possibilidades geradas na simultaneidade entre os instrumentos.

Abordadas como momentos informais e participativos, as experimentações eram entremeadas de comentários, perguntas e novas provocações de todos(as) os(as) participantes do grupo, enriquecendo ainda mais as trocas e explorações. Assim, nessa primeira etapa, da minha perspectiva, a experimentação foi um veículo para a interação colaborativa, para a demonstração, para o compartilhamento e para a descoberta de possibilidades sonoras e estruturais.

\section{FLAUTISTA (Gina, que escreve em sua língua pátria)}

Nuestro primer taller de creación colaborativa fué un momento de troca y exploración de ideas sonoras, gestuales y expresivas, todos(as) tocamos individualmente y fuimos escuchados por los(as) otros(as) cuatro compañeros(as) del Coletivo N.S.L.O. Tocamos piezas y/o fragmentos de piezas, así como pasajes aleatorios que considerábamos representativos, tanto de las predilecciones estéticas de cada uno(a) de nosotros(as), como del idiomatismo de cada instrumento. Tocamos también, a modo de miscelánea, sonidos, articulaciones, técnicas extendidas, efectos, posibilidades, terminamos jugando con y en el instrumento. Probamos los límites de nuestra técnica y de nuestro instrumento en aquel momento. En el caso de la flauta, exploramos posibilidades de frulatto de lengua o garganta, de cantar y tocar, de armónicos, de whistle tone, de susurros en la flauta, de trinos y trémolos no convencionales y otras tantas relaciones. También, combinaciones de registro-dinámica-articulaciones-calidades de sonido fueron probadas en ese espacio de experimentación. En las búsquedas de lo que "mejor funcionaba", quedaban en evidencia combinaciones que "no funcionaban tan bien"; estas no eran excluidas y si guardadas como potenciales posibilidades expresivas. Estos saberes podían ser, o no, obvios para cada uno(a) en su instrumento, pero ahí, en ese ir y venir de ideas y tentativas, estábamos en un momento de socialización, de aprender juntos(as), de conocernos y reconocernos mejor.

En un segundo momento, Heitor nos invitó a un juego sonoro entre el piano y la flauta; mientras los otros integrantes del colectivo nos escuchaban y observaban con atención, él tomaba apuntes. Entre tanto, Dario y yo tocábamos de manera libre. Espontáneamente, iba surgiendo un dúo que construíamos juntos por medio de la exploración en el instrumento y del diálogo (escucha y interacción) con las propuestas del otro. Esta primera experiencia de juego a dúo de flauta y piano (por Dario y yo) fue el punto de partida para ...sururus..., un momento en que pudimos (nosotros mismos y los demás integrantes del colectivo) tener una idea inicial de nuestras posibilidades sonoras como dúo. 


\section{PIANISTA (Dario)}

Da nossa oficina, destaco dois momentos os quais considero essenciais para nossos processos criativos e colaborativos.

O primeiro caracteriza-se pela expressão de nossas identidades musicais, trazidas à tona através da exploração das possibilidades sonoras em nossos instrumentos - técnicas expandidas, sons, gestos físicos e trechos musicais prediletos de peças do repertório -, bem como a discussão sobre os motivos que fundamentam nossa identificação com esses elementos.

O segundo momento foi o de atribuir significados a essas expressões de nossas identidades através de jogos. Quando digo jogos, refiro-me às experimentações feitas em resposta às provocações do compositor e dos demais intérpretes do grupo. Nessa etapa, surgem contornos mais definidos nas interações e diálogos entre os horizontes musicais de cada um(a) do grupo. Foi também um momento de negociações sobre o que poderíamos criar e expressar com essas sonoridades e respectivos significados.

Ideias germinais que se manifestaram durante esse segundo momento foram percebidas como potenciais para subsidiar narrativas de algumas das peças criadas pelo Coletivo N.S.L.O. Quando Renan e Sabrina se sentaram um de frente para o outro e deram início a uma série de experimentações em que um interferia no violão, corpo e posicionamento do outro, observamos ali possibilidades de cenas conflituosas que se vinculavam fortemente com o plano de fundo proposto pelo compositor: uma cena de Macbeth, de William Shakespeare. Similarmente, as experimentações entre Gina e eu geraram resultados musicais aos quais começamos a designar certas características, como frases sobrepostas simulando conversas cruzadas, sons invasivos, falas concordantes e discordantes, que vão ao encontro da proposta presente no próprio título da obra: ...sururus e quiprocós...

\section{VIOLONISTA 1 (Renan)}

Como lidar com a indeterminação na performance de música de concerto? Nossa primeira semana de atividades do grupo, quase toda reservada para nossas atividades internas, proporcionou-me o desabrochar de uma faceta ainda não explorada na música de concerto. A indeterminação em música era quase um assunto tabu para mim, mesmo após muitos anos de vivência na música popular, contexto no qual os momentos abertos à improvisação eram, quase sempre, cuidadosamente estudados antes do ensaio ou apresentação. Chegada a hora de nossas primeiras experimentações junto ao grupo, em nossas oficinas de Porto Alegre (RS), senti uma espontaneidade incrivel: o medo de não reagir da forma "mais adequada" à indeterminação é o mesmo medo de "errar" ao tocar em público ou em ensaios, o que se origina a partir do nosso perfeccionismo, do nosso orgulho. Daí, questões que eu já havia resolvido em relação à performance em público, do "medo de errar", me auxiliaram prontamente em relação ao "medo de reagir de forma inadequada à indeterminação" - o que não dispensa, logicamente, a prática e o estudo da experimentação em si.

De nossas primeiras oficinas realizadas, destaco o momento em que apresentei aos colegas de grupo trechos de músicas que eu acredito que me representam em meu 
melhor. Aí me dei conta de que, por mais que estejamos trabalhando com linguagens musicais do século XX e XXI, sempre haverá elementos de outros períodos históricos em minha performance, afinal, somos intérpretes que estudamos e tocamos músicas de outras épocas. Há um quê de racionalidade renascentista, de intensidade barroca, de coesão clássica e de lirismo romântico no que toco, e isso é uma parte indissociável do meu fazer artístico.

Outro momento muito marcante foi a primeira vez que Sabrina e eu realizamos uma experimentação frente a frente. As possibilidades expressivas, discursivas e técnicas pareciam infinitas, mas ao mesmo tempo limitadas, dada nossa necessidade de colocar molduras em nossas ações - uma necessidade talvez apreendida, naturalizada. Foi um momento mágico que abriu portais de nossas percepções.

\section{VIOLONISTA 2 (Sabrina)}

Os jogos, células e interações da etapa de colaboração criativa do projeto receberam um contorno delineado pela discussão dos questionamentos instigantes propostos pelo compositor. As perguntas sobre nós músicos/musicistas (como apresentar cada um em seu melhor?) e as discussões sobre a forma de escrita e apresentação da estrutura e dos materiais de ...repartido e ...sururus... nos renderam uma experiência de experimentação única.

A configuração espacial proposta para a experimentação, até então nunca vivenciada por nós, trouxe o estímulo de que eu particularmente necessitava para me permitir uma experiência incomum: deveríamos testar configurações para mim até então inusitadas, como, por exemplo, tocar frente a frente, de costas, de lado, próximos e distantes. Por fim, posicionados um de frente para o outro, Renan e eu testamos o que seria uma seção indeterminada que constituiria a obra.

A experimentação para ...repartido foi baseada no pano de fundo dramático que motivou a obra, nas discussões sobre como nos vemos e expressamos enquanto músicos/musicistas, e nos materiais sonoros e gestuais que surgiam a cada tentativa de performance. Os(As) demais integrantes do grupo também participaram, criando e nos confrontando com ideias interessantes sobre como poderíamos conduzir as ações e o discurso musical. A utilização de cordas soltas, clusters, ideias melódicas e harmônicas, ligados, tamboras, pizzicato Bartók, harmônicos e percussão no corpo do violão não foram os únicos recursos imaginados, e esse é o fato que mais me chamou a atenção nessa primeira etapa do projeto.

A sensação de liberdade criativa corporal foi intensa e nos permitiu conceber diferentes recursos sonoros e visuais até então não experimentados por nosso duo de violão. Atitudes como: desafinar o violão de Renan, impedi-lo de tocar, interrompendo o percurso de seus gestos, e interferir nas cordas de seu violão, produzindo sons percussivos, partiram naturalmente das discussões iniciais e integraram significados interessantes à narrativa que se delineava naquele momento. Havia a percepção de uma relação de interdependência entre a serenidade ou impetuosidade com que realizava meus gestos e a criação de conexões ou quebras nos diálogos estabelecidos com Renan e com o todo. Assim, a partir desse evento de experimentação, foi possível entrever 
de que forma eu poderia imprimir minhas ideias e conduzir as impressões do público sobre o tema proposto.

\section{COLETIVO}

$\mathrm{Na}$ discussão sobre a oficina, destacamos os questionamentos e provocações apresentados pelo compositor e a experimentação como veículo para a interação colaborativa. Sobre esse aspecto, a flautista e o pianista rememoraram o primeiro momento em que trocaram ideias a respeito dos materiais sonoros que mais os agradaram e, em seguida, o momento de significação dessas sonoridades através do estímulo de jogos. Para os violonistas, a oficina criativa colaborativa desmistificou o assunto da indeterminação, o que se deu a partir da experiência de novas configurações espaciais e possibilidades que geraram uma maior expressividade corporal. Observa-se aí a via de mão dupla entre as provocações levadas à oficina pelo compositor e as respostas a essas provocações devolvidas pelos(as) intérpretes através das experimentações aos instrumentos, formando um ciclo em constante atualização.

Assim, nas colaborações desenvolvidas pelo Coletivo N.S.L.O, as divisões dos papéis - intérpretes e compositor - foram mantidas, mas destaca-se a flexibilidade em nossas relações. Essa dinâmica já havia sido observada por Dario em sua tese "Processos criativos colaborativos na música contemporânea: dois estudos de caso" (2019), em que analisa uma colaboração anterior desenvolvida com o compositor Heitor durante a criação da obra As gerações dos mortais assemelham-se às folhas das árvores (2017). A partir da análise de vários registros e documentações provenientes desse processo, Dario identifica a manutenção da divisão dos papéis, porém, constatando também um "[...] envolvimento intenso do intérprete em decisões estruturais da obra, em reorganizações de materiais e na criação conjunta de ideias que influenciaram diretamente a narrativa e escrita da peça" (SILVA, 2019, p.151).

Da mesma forma, no Coletivo N.S.L.O, o grau de manutenção e flexibilidade dos papéis tradicionais de compositor e intérpretes não resulta do automatismo de uma hierarquia verticalizada, mas é mediado de maneira horizontal pelas relações de confiança e pelas distribuições de tarefas negociadas no interior do grupo, no processo de construção de cada peça/performance. No entanto, embora com significativo grau de intensidade, a flexibilidade percebida em nosso grupo difere dos exemplos anteriormente citados de Östersjö (2008) e Ishizaki \& Machado (2013); as flexibilidades observadas nos exemplos desses autores possuem contornos ainda mais intensos em razão das ocorrências de borramentos entre os papéis de compositores e intérpretes.

Para fins comparativos, um possível exemplo oposto, ou seja, de relações em que as flexibilidades são menos intensas, seria uma situação em que os diálogos entre as partes ocorrem de acordo com a predominância de uma hierarquia ou relação vertical, onde o espaço que um lado tem para expressar suas ideias é desproporcional em comparação ao do outro. São relações de naturezas distintas e que exigem separações quando falamos em interações entre intérpretes e compositores. Embora o termo colaboração possa ser utilizado para designar variados tipos de interações, algumas dessas interações possuem propostas e perfis bem definidos, uma vez que, por exemplo, “[...] 
envolvem a encomenda de um trabalho, um processo no qual os papéis individuais são tipicamente mantidos separados"20 (CARDASSI, 2011, p.31, tradução nossa). Domenici observa que "[...] o trabalho colaborativo coloca compositor e performer em uma relação horizontal caracterizada pelas inter-relações entre a oralidade e a notação" (DOMENICl, 2013, p.2).

Quanto ao resultado estético, a proposta composicional é ressignificar a situação de performance musical como espaço de representação. Essa abordagem afeta o papel da experimentação como mediação das interações entre compositor e intérpretes na fase exploratória do processo criativo, na medida em que as experimentações são avaliadas não apenas em termos de seus resultados sonoros, mas em sua teatralidade, ou seja, em suas dimensões multissensoriais e possibilidades de construção de sentidos narrativos. Também devido a essa proposta estética, a delimitação de estratégias de indeterminação na escrita e jogo na performance são construídas não por preferências técnicas ou estéticas prévias, mas em decorrência do ajuste de demandas musicais, performativas e narrativas no decorrer do próprio processo criativo de cada peça.

\section{Jogos e interações em ....repartido}

...repartido é uma peça para casal de violonistas e assistência, com difusão sonora. Sua estreia ocorreu na segunda etapa do projeto do Coletivo N.S.L.O, em Mossoró (RN), tendo ocorrido novas performances nas duas etapas seguintes, em Ribeirão Preto (SP) e Cali (Colômbia).

\section{COMPOSITOR (Heitor)}

Trabalhei na escrita de ...repartido a partir do meu próprio planejamento e das impressões extraídas das experimentações realizadas na primeira etapa do projeto do Coletivo N.S.L.O. A impressão mais marcante daquela fase exploratória era que as diferentes possibilidades de posicionamentos e relações estabelecidas entre o casal de violonistas/protagonistas seria o principal fator de articulação estrutural para a peça. Assim, o planejamento foi revisto, de tal maneira que as referências a Shakespeare ficam diluídas e a organização da partitura/roteiro projeta condições corporais e espaciais de realização da performance. Esse tipo de diluição, de uma referência literária inicialmente assumida como estímulo para organização estrutural/narrativa da composição, tem sido recorrente em minha prática, constituindo um traço dessa abordagem. Parece-me estar relacionado ao delicado equilíbrio entre a apresentação direta de sons e ações (performance) e o surgimento de intermitências ficcionais (representação), implicado no meu interesse pela teatralidade das situações de performance musical. Assim, mesmo quando a narrativa da referência literária original não é explicitada para o público, ela cumpre papel relevante no processo criativo, ao servir de impulso e fator de organização subjetiva da escrita, e no resultado estético, por direcionar a seleção e apresentação de elementos estéticos particularizados.

20 Original: "[...] many of which involve the commission of a work, a process in which the individual roles are typically kept separate" (CARDASSI, 2011, p.31). 
Outra importante conclusão extraída da fase exploratória foi que algumas das possibilidades vivenciadas para essa peça deveriam adotar a escrita indeterminada na versão final da partitura/roteiro, pois não seria desejável fixar a dinâmica que o fluxo da performance interativa entre o casal de violonistas imprimia a essas ações. Assim, a partitura conta com dois episódios de escrita indeterminada, delimitando critérios para a performance por meio de indicações verbais que remetem tanto à própria escrita musical quanto aos elementos dramáticos shakespearianos, que servem como ímpeto expressivo para mim e para o casal de intérpretes.

R. improvisa com trechos e motivos da partitura, mas é interrompido e olha na direção de sons repentinos e espaçados produzidos pelos assistentes.

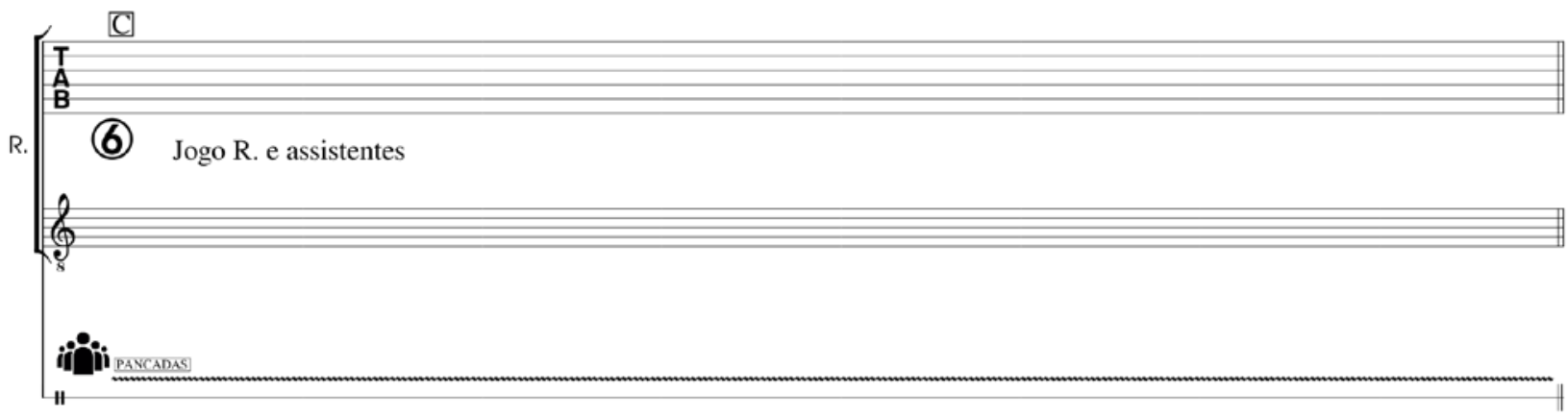

Fig. 1: Jogo entre Renan e assistentes

No Episódio 6 da peça (Figura 1), a que nos referimos entre nós como "Jogo das pancadas", Renan é constantemente interrompido pelos assistentes, que produzem ruídos pontuais à sua volta. O jogo remete à indicação cênica "Pancadas dentro" da Cena II do Ato II de Macbeth, na qual o protagonista reage com pavor ao ouvir ruídos que o fazem temer ser descoberto por seu crime. 
R. e S. improvisam com trechos e motivos da partitura, mas se interrompem, interferindo um no violão do outro. Depois largam os violões, levantam-se e continuam a interferir um no outro (mexer em roupas, cabelo).



Fig. 2: Jogo entre Renan, Sabrina e assistentes

O Episódio 7 (Fig. 2), por sua vez, implica uma referência mais difusa ao enredo dramático, refletindo a deterioração final do relacionamento entre Macbeth e Lady Macbeth. Posicionados frente a frente, Renan e Sabrina se lançam a um embate que começa na esfera sonora e progride para a física até o ponto em que as ações instrumentais são abandonadas.

\section{VIOLONISTA 1 (Renan)}

Na performance de ...repartido, lidamos com diferentes scordaturas para os dois instrumentistas. Enquanto eu toco com o violão afinado em Sol Maior (da 1a para a 6a cordas: Ré, Si, Sol, Ré, Sol, Ré), Sabrina tem seu violão afinado em Lá Menor (da 1a para a 6 cordas: Mib, Si, Láb, Mib, Láb, Mib, com capotraste na primeira casa). Isto proporcionou uma nova perspectiva de performance, com novos "desenhos", novas fôrmas, em relação ao que estamos acostumados na afinação mais convencional do instrumento. Por querer remeter ao material musical da peça nas seções indeterminadas, eu geralmente direciono a performance a partir de "desenhos" no braço do instrumento. Dessa forma, em vez de pensar em notas musicais, na nova scordatura, tenho pensado, majoritariamente, em "desenhos" similares aos das partes escritas. Ademais, vou me permitindo, de forma livre, desenvolver coisas novas, com o pensamento ainda focado em desenhos, não em notas. Penso que, em performances futuras, eu posso fundamentar minhas escolhas em outras questões.

$\mathrm{Na}$ experiência frente a frente com Sabrina, a performance é extremamente fragmentária quanto a notas musicais, procedimentos técnicos ou ações nos instrumentos - no meu e no de Sabrina. Neste momento, a única coisa que tenho em mente é fazer o 
melhor crescendo geral de sonoridade/ações, o que culmina com nosso embate físico o último degrau do nosso crescendo de ações, que é continuado, quanto à sonoridade, pela difusão sonora.

\section{VIOLONISTA 2 (Sabrina)}

Destaco em ...repartido, dentre ações musicais e não musicais, minha ação no contexto do jogo das pancadas e o jogo frente a frente com Renan. Participo, em cada uma dessas situações, a partir de estímulos e meios de interlocução diferentes $\otimes$ ora através de decisões musicais e gestos, quando me encontro posicionada com o próprio instrumento, ora sem o recurso sonoro do violão.

Sobre este último, cito o jogo das pancadas, momento no qual o público/assistência, a partir da emissão de "pancadas", influencia para onde o Renan deve direcionar o seu olhar, perseguindo os sons produzidos. Nessa seção da peça, minha ação é perceber as intenções que definem a dinâmica do jogo e, com base nessa percepção, tomar a decisão do momento em que devo interrompê-lo e dar sequência à peça. Quando decido caminhar em direção ao Renan, me posicionando frente a frente com ele, os assistentes deixam de produzir as pancadas e se preparam para o início da seção seguinte. Apesar de não participar ativamente da cena, durante todo o processo há a necessidade de que eu esteja atenta às intenções do jogo, para assim definir o momento de quebra do discurso construído.

No primeiro momento do jogo, frente a frente com Renan, tocamos nossos instrumentos partindo de intenções musicais e gestuais lentas e intervaladas. À medida em que o diálogo é construído, gestos de interferência no violão um do outro passam a se intensificar, até o ponto em que a assistência segura os violões, culminando em um momento no qual encenamos um embate físico, que marca o início da seção final da peça.

Essas duas situações, apesar de serem fundamentadas em um roteiro preestabelecido, contam com a imprevisibilidade de uma série de fatores que influenciam nas decisões que tomamos diante das possibilidades que temos - dentre os quais, o espaço e a assistência disponíveis. ... repartido teve sua estreia em Mossoró (RN) e foi apresentada novamente em Ribeirão Preto (SP) e em Cali (Colômbia). As três performances da peça contaram com situações de público/assistência e configuração espacial bastante diferentes, para as quais tivemos que nos preparar em poucos dias. Como exemplo, em Mossoró (RN), apesar do espaço físico pouco estruturado, contamos com um público assistente numeroso. Em Ribeirão Preto (SP), contamos com um número reduzido de público e assistentes, mas com um espaço físico extremamente interessante visualmente. Já em Cali (Colômbia), a peça foi produzida em caráter de instalação, onde nós adaptamos toda a estrutura necessária para viabilizar sua apresentação no salão de entrada da instituição na qual estávamos realizando a quarta etapa do projeto, e contamos exclusivamente com a assistência dos integrantes do próprio grupo e com o público transeunte que se interessou pela intervenção que propusemos.

Sendo assim, pontuo que minhas percepções, nas performances vivenciadas nas duas seções indeterminadas da peça, foram distintas em cada uma dessas experiências. Sobre essa questão, vale pontuar que, em Cali (Colômbia), me senti mais desafiada 
em todos os sentidos, já que a configuração e a iluminação do cenário permitiam que o público me visualizasse mais nitidamente. Da mesma forma, eu percebia melhor as reações do público, fato que influenciou no modo como eu decidia me movimentar no cenário. Como exemplo, no jogo frente a frente com Renan, senti a necessidade de observar mais atentamente os movimentos corporais, e, no jogo das pancadas, percebi que seria importante me manter mais vigilante quanto à minha expressão facial durante minha espera, até o momento de interromper o jogo.

\section{COLETIVO}

Ao introduzir a discussão sobre ...repartido, Heitor pontua que, apesar da narrativa da referência literária original não ser explicitada para o público, ela cumpre papel relevante no processo criativo e se concretiza nas indicações verbais para a performance, as quais remetem tanto à própria escrita musical quanto aos elementos dramáticos shakespearianos. Renan pontua que desenvolve um modo de pensar a peça em desenhos no braço do instrumento, se desprendendo do hábito de pensar nas notas. Sabrina destaca as diferentes percepções em dois momentos distintos de jogo, onde há também tarefas não ligadas à execução instrumental.

O aspecto expressivo guia o estabelecimento de um jogo de ações com e sem implicações sonoras, instrumentais e cênicas. A escrita indeterminada vale-se de indicações verbais, tornadas relevantes no contexto da experiência compartilhada entre compositor, violonistas e todo o grupo, no processo criativo da peça. Nesse caso, a experimentação da fase exploratória e o jogo estabelecido no momento da performance medeiam as intenções expressivas dos agentes dessa criação musical.

\section{Sorteios, platôs e percursos em ...sururus....}

...sururus... também teve sua estreia na segunda etapa do projeto do Coletivo N.S.L.O, em Mossoró (RN), com performances adicionais nas duas etapas seguintes, em Ribeirão Preto (SP) e Cali (Colômbia). É uma peça para flauta, piano e assistência, com difusão sonora.

\section{COMPOSITOR (Heitor)}

A experiência de provocar e observar a experimentação com ideias musicais estáticas (platôs) e transições (percursos), realizada na oficina da primeira etapa do projeto do Coletivo N.S.L.O para ...sururus..., me convenceu que a escrita deveria adotar um mecanismo de indeterminação que permitisse trazer para a peça a abertura e a variabilidade de simultaneidades constatadas naquela exploração inicial. Para isso, escrevi a peça em 25 módulos, sendo que cada módulo contém um platô - parte estática, obrigatória, que pode ser repetida ad libitum -, um percurso de entrada e um percurso de saída - partes opcionais que podem ser usadas para fazer a transição entre os platôs de dois módulos distintos.

A partitura é apresentada concretamente aos intérpretes em chapas metálicas, sendo os módulos impressos em cartões com mantas magnéticas (ver Fig. 3, a seguir). Com esse material e um par de dados, intérpretes e dois assistentes (um designado para 
cada intérprete) se envolvem em um jogo no qual o número de módulos e os módulos específicos disponíveis ao longo da execução são objeto de sucessivos sorteios e escolhas aleatórias. Nesse jogo, a performance é construída com módulos disponíveis, sendo livre o número de repetições, alternâncias e pausas.

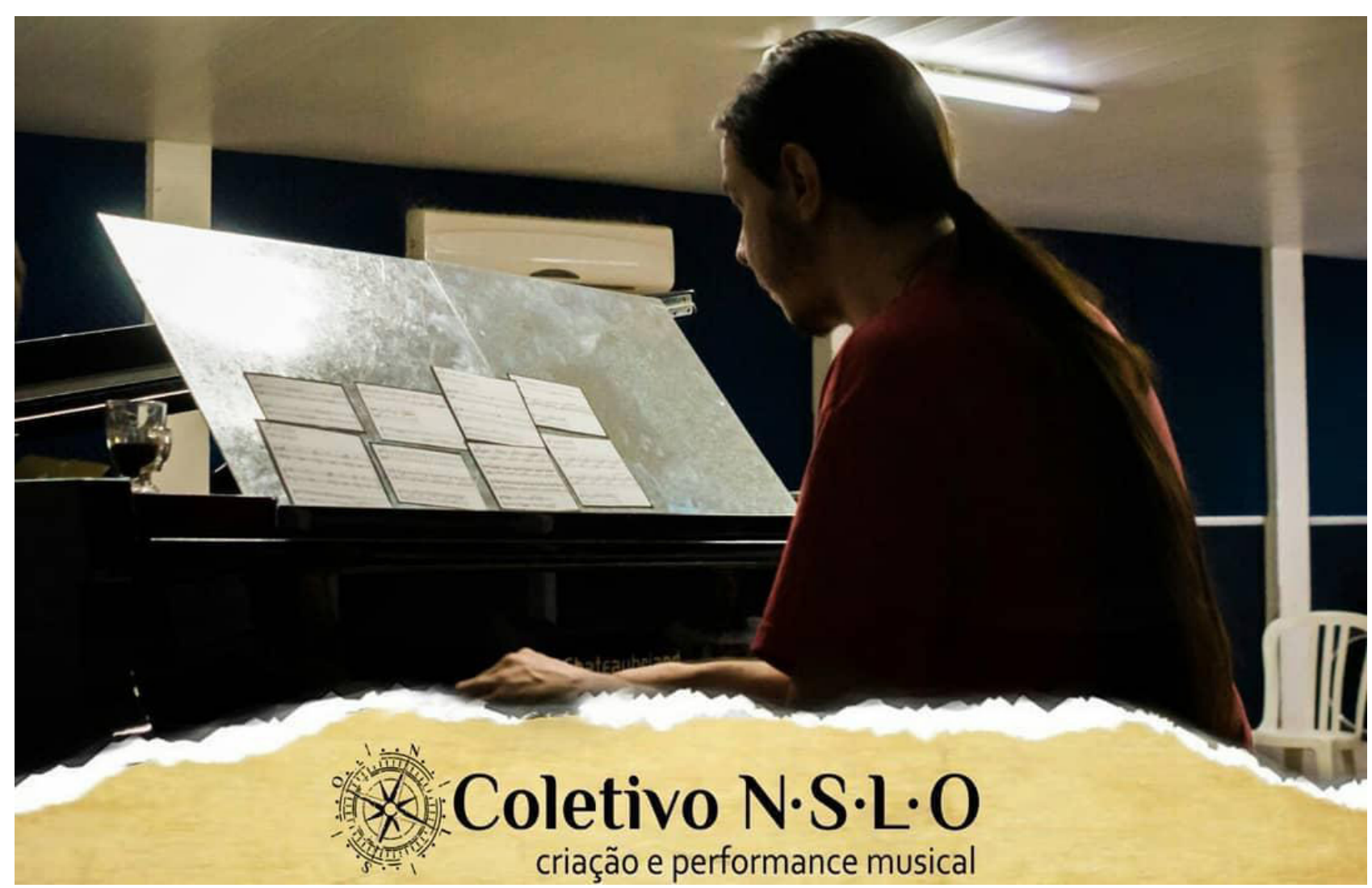

Fig. 3: Dario com chapa metálica e os módulos impressos em cartões com manta magnética ao piano, durante uma performance de ...sururus...

Paralelamente, instrumentistas e assistentes são impulsionados por uma sequência de episódios cujas transições são previamente convencionadas por meio de ações, difusões sonoras ou mudanças na iluminação (ver Quadro 2). Além dos materiais instrumentais descritos no parágrafo anterior, a realização de ...sururus... também se vale de materiais sonoros pré-gravados, objetos obsoletos trazidos pelos(as) participantes e materiais para vocalizações, consistindo em cartões com frases e expressões obsoletas impressas. 
Assistente da flautista realiza primeiro sorteio e disponibiliza módulos da parte de flauta (depois continua sorteando ad libitum);

Flautista inicia execução instrumental;

Após um tempo, e aproveitando um momento de mudança no plano sonoro da flauta, um assistente entra trazendo um objeto obsoleto que expõe ao público;

Os demais assistentes entram e expõem também seus objetos obsoletos tomando seus lugares no espaço entre instrumentistas e plateia;

Flautista continua execução solo por um tempo;

Entra primeira difusão sonora;

Assistentes começam a realizar ações, interagindo com seus objetos, enquanto pianista começa a aplicar rótulos;

(Assistente do pianista realiza primeiro sorteio e disponibiliza módulos da parte de piano, continuando a sortear posteriormente, ad libitum);

Após algum tempo, a primeira difusão sonora é retirada;

Assistentes retornam aos seus lugares e pianista retorna ao piano;

Pianista começa a tocar e flautista para de tocar;

Pianista continua execução solo por um tempo;

Entra segunda difusão sonora;

Flautista começa a distribuir cartões com frases e expressões obsoletas;

Assistentes e plateia criam um burburinho vocal, jogando com as frases;

Depois de um tempo, a segunda difusão sonora é retirada;

Assistentes recolhem todos os cartões e cessa o burburinho;

Flautista volta a tocar, unindo-se ao pianista;

Ambos tocam por um tempo;

Entra a terceira difusão sonora, o duo segue tocando;

Depois de um tempo, a terceira difusão sonora é retirada;

Assistentes do pianista e da flautista param de sortear, deixam os módulos restantes do último sorteio disponiveis para os instrumentistas;

Flautista e pianista continuam tocando por um tempo e, em consenso, encontram um final para a peça.

Quadro 2: Sequência de ações para performance de ...sururus...

Os módulos foram escritos originalmente com partes síncronas, mas, devido à imprevisibilidade do sorteio, a coincidência de módulos entre flauta e piano tornou-se uma contingência a ser concretizada ou frustrada pelas circunstâncias de cada performance. As combinações fortuitas entre módulos distintos proporcionam a proliferação de possibilidades rítmicas e harmônicas dos materiais musicais. Flautista e pianista moldam o resultado expressivo com decisões locais sobre ordem e quantidade de repetição na execução dos módulos, bem como a partir da liberdade de buscar relações entre as partes, por meio de nuances da dinâmica e articulação, reagindo ao que ouvem e aos demais acontecimentos que transcorrem na performance. 


\section{FLAUTISTA (Gina)}

Desde nuestra primera experiencia en el taller de creación colaborativa y en todas las siguientes, siempre hemos tenido la sensación de grata sorpresa con lo que surge. ...sururus... ya fue tocada en tres ocasiones, cada una con diferentes características de público (sala llena, público reducido y público transeúnte), lugar (condiciones de espacio, acústica e instrumento - piano o clavinova) y contexto (concierto y instalación).

La pieza se construye a partir de la aleatoriedad para "caer" en los módulos y de las decisiones que tomamos para interpretarlos. Los platôs presentados en los módulos son de repetición libre, y en esa libertad para hacer, interpretar, decidir y proponer, nuevos alcances de responsabilidad, autonomía, creatividad e interacción caen en la mano del/ de la intérprete. Ahí entran en juego metáforas conceptuales como la música es como la vida, la vida es un juego, la música es un juego.

...sururus... inicia con una sección mía a solo; en ella generalmente procuro presentar los módulos sin hacer mayores alteraciones, manteniendo el carácter que la notación de cada uno me sugiere y pasando por la mayoría o por todos los que el sorteo me coloque. La naturaleza introductoria de esta sección ha sido el motivo de mis decisiones interpretativas, entre tanto, en próximas ocasiones probaré nuevas maneras de manipular los recursos.

Más adelante, experimentamos a dúo de flauta y piano, ahí "la cabeza va a mil" pues ahora el juego implica a un "otro". Todo ocurre en tiempo real y las decisiones se toman en la hora, escucho a mi compañero, percibo el fluir energético y emotivo de los elementos sonoros y visuales confluentes, tomo micro-decisiones en micro-segundos. Con cuál módulo voy a entrar? Con cuál nivel de presencia: sutil, con más presencia, en contraste? Con cuál carácter: mantengo el carácter que transcurre, lo voy transformando? En cuál dinámica: forte, piano, mantengo la dinámica, hago crescendo, decrescendo, cambios súbitos? Con cuál pulso: lo mantengo, lo vario? Con cuáles elementos juego en el platô: aumentaciones o disminuciones rítmicas, articulaciones, calidades de sonido etc? Continúo como si fuese un mantra? Cuál es límite de un recurso? Y así sucesivamente.

Durante el performance esas preguntas, por lo menos en mi cabeza, no aparecen literales o en ese orden, pero si están implícitas dentro de las micro-decisiones que ocurren en un ambiente de indeterminación, deliberación y estado de flujo, a veces acompañadas de una muy leve ansiedad, que aún no sé si hace parte o si desaparecerá con más tiempo de juego e experimentación. Analítica y existencialmente vale la pena preguntarse de dónde puede venir esa ansiedad, será que una situación de indeterminación nos asusta? Será que cuando tenemos libertad no sabemos lidiar con ella? Será que nos acostumbramos a los "confortos" de seguir discursos preestablecidos y canonizados? Será que perdimos la costumbre de imaginar, arriesgar, crear? Será que el acto natural de crear se ha desnaturalizado?

Tocamos en público en las ciudades brasileñas de Mossoró (RN) y Ribeirão Preto $(S P)$, y en Colombia, en la ciudad de Cali. Después de estas tres experiencias de performance, comienzo a tener material (memorias y grabaciones) para observar y reflexionar. Ahí comienza el ejercicio de ver evoluciones, recurrencias e in-permanencias, comienza a haber material para "darse cuenta de...". Haciendo una retrospectiva sobre nuestras 
performances, y observándome, percibo refinadas capacidades de escucha y de interacción con el otro, con las difusiones sonoras y con las circunstancias. No obstante, por otra parte, percibí una cierta "pasividad" (en el sentido de pasivo/activo) de mi parte para proponer nuevas ideas en los juegos, o también una falta de fuerza cuando propongo, todo eso en un nivel muy sutil, pero presente.

A partir de aquello abro una serie de cuestiones buscando los posibles orígenes de este fenómeno: esa pasividad podría venir de una formación donde principalmente estudié repertorio tradicional "al pie de la letra"? De pre-concepciones sobre la potencia o presencia del instrumento, flauta en relación al piano? De los resquicios de una musicista formada en medio de una sociedad patriarcal? De miedo, inseguridad? De algunas o de todas las anteriores? La situación para crear las preguntas ya fue dada, ahora me resta continuar experimentando, jugando, observando, comprendiendo, resignificando, transformando.

\section{PIANISTA (Dario)}

Os estímulos imagéticos que auxiliam minhas abordagens interpretativas para essa peça estão vinculados a determinados tipos de ambientes, como, por exemplo, os bares. Atribuo essa conexão às minhas observações acerca dos tipos de diálogos que geralmente ocorrem nesses ambientes: os variados assuntos que, por vezes, surgem de maneira aleatória nas mesas são como os 25 módulos musicais da peça sorteados pelos assistentes; o prolongamento nesses assuntos e as várias maneiras através das quais os interlocutores podem abordá-los, vejo como as repetições ou platôs; os percursos, as conexões entre assuntos ou a inserção abrupta de um novo tema sem qualquer tipo de conexão ou preparação, uso para moldar as minhas inflexões e conduções nos momentos em que preciso transitar entre os módulos. São ampliações das ideias exploradas nas etapas iniciais de nossas oficinas.

Esse tipo de contexto fornece substratos criativos para que eu possa gerenciar o fluxo da peça, o que considero um dos aspectos fundamentais de sua expressividade. Durante a performance, minhas atenções voltam-se para o fornecimento contínuo ao ouvinte de inusitadas sobreposições de linhas, nuances e caráteres das minhas interpretações dos módulos com os de Gina. Busco uma espécie de caleidoscópio de sensações, fazendo com que a cada movimento, seja ele proveniente da aleatoriedade dos sorteios ou das decisões interpretativas minhas e de minha parceira, produza novas combinações, cores e formas.

\section{COLETIVO}

No processo de criação de ...sururus..., Heitor propõe um mecanismo de indeterminação que permite trazer, para a peça, a abertura e a variabilidade de simultaneidades constatadas na exploração da oficina inicial. Gina destaca que há uma certa ansiedade na imprevisibilidade das decisões musicais gerada pela aleatoriedade dos módulos sorteados. Dario destaca a preocupação que tem de fornecer continuamente, para o ouvinte, sobreposições inusitadas de linhas, nuances e caráteres nas interpretações que dá aos módulos, juntamente com Gina. 
Os aspectos relacionados ao resultado expressivo de ...sururus..., supracitados por Dario e Gina, atestam a importância das relações interdependentes e sinergéticas nessa e em outras obras criadas pelo Coletivo N.S.L.O. Em ...sururus..., ocorrem sorteios realizados por assistentes que decidem quais, quantas e com que frequência as células musicais (módulos) serão dispostas a ambos para que as toquem repetidamente. No entanto, não há indicações de tempos metronômicos, rubricas sobre o caráter expressivo desses módulos ou a quantidade de repetições necessárias. São aberturas presentes na escrita das quais Dario e Gina se apropriam para criar os diálogos e jogos: um determinado módulo pode ser expresso com vários humores, inflexões, timbres e nuances diferentes a cada sorteio ou repetições. As várias nuances expressivas da obra não se concretizam se a flautista e o pianista adotarem uma atitude isolada ou indiferente em relação ao que o outro está fazendo. O modo como Dario molda suas expressões com os módulos é diretamente influenciado e dependente do retorno que Gina lhe fornece sobre alguma sensação observada durante a performance e vice-versa. Se algo os agrada ou desestabiliza durante a execução pública, um ou outro pode fazer uso desses estados emocionais observados para criar as dinâmicas dos jogos.

\section{Considerações finais}

As características deste projeto, cujo desenvolvimento se dá paulatinamente em etapas cronologicamente distantes umas das outras, contemplam, além dos registros do processo criativo e performances, nossas reflexões faladas e escritas, o que nos permite compreender essa prática colaborativa nos campos da composição e da performance musical.

O Coletivo N.S.L.O surge e se desenvolve pelo desejo de compartilhar experiências de colaboração criativa, em uma proposta artística que foi aqui discutida a partir dos conceitos de flexibilidade dos papéis criativos e indeterminação da escrita. Sobre o primeiro, observamos que, apesar das divisões dos papéis - intérpretes e compositor - serem mantidas entre nós, destaca-se a flexibilidade no modo como regemos cada oportunidade de colaboração, com a distribuição de tarefas negociada no próprio processo de construção de cada peça/performance, o que faz com que nossas relações fluam de maneira horizontal, permitindo que as ideias transitem em ambos os sentidos (composição - performance e vice-versa). Sobre o segundo, destacamos a proposta composicional de Heitor, que, devido ao seu interesse na teatralidade da performance musical, propõe situações cênico-musicais como ponto de partida para a organização de materiais musicais, verbais, corporais e visuais, incluindo as possibilidades expressivas oferecidas pela indeterminação.

Na prática do Coletivo N.S.L.O, a colaboração é concretizada por meio da experimentação, cujo lugar no processo criativo é de mediação entre os trabalhos de composição e construção da performance. No processo de criação consagrado na música de concerto de matriz europeia, há uma separação entre o trabalho do(a) compositor(a) - planejamento e escrita - e o trabalho dos(as) intérpretes - construção da performance. No processo colaborativo aqui relatado, a experimentação cria um espaço em que 
compositor e intérpretes atuam juntos de maneira decisiva para o resultado criativo alcançado. Na perspectiva do compositor, a experimentação the permite agregar suas concepções e percepções sobre a construção da performance, revendo aspectos do seu planejamento para incorporar os resultados da experimentação à escrita, por meio da indeterminação. Desse modo, a experimentação também permite que possibilidades concretizadas pelos performers sejam agregadas à própria concepção da peça. Intérpretes incorporam os resultados da experimentação à construção da performance por meio do estabelecimento de jogos, constituídos por materiais musicais, ações e interações.

A experimentação mediou nossas práticas de composição e performance nas fases exploratórias dos processos criativos e na realização de aspectos específicos de nosso repertório. Integrada aos demais recursos estéticos das peças - difusões sonoras, iluminações, ações, interações com o público, preparações de ambientes, objetos e percursos -, a indeterminação agrega possibilidades sonoras e cênicas únicas e pertinentes às intenções expressivas do grupo. O diálogo que estabelecemos com as técnicas e tradições da criação musical, da segunda metade do século XX até o presente, é submetido ao filtro de um projeto artístico emergente das interações concretas no decorrer dos encontros do Coletivo N.S.L.O e de aspectos sensíveis que nos impulsionam a prosseguir com esse trabalho.

Do ponto de vista de uma poética composicional, a indeterminação abarca distintas possibilidades de ênfase: a abertura ao acaso, a escolha do(a) intérprete na construção da performance e a instauração de um jogo de ações, interações e sentidos. $\mathrm{Na}$ medida em que nossa proposta se alia mais a esta última ênfase, a escrita indeterminada e a construção das performances visam criar situações de interação entre intérpretes, assistentes e público. Do ponto de vista da técnica composicional, os elementos indeterminados ora referem-se aos materiais sonoros, ora ao contorno formal, em consonância com a construção narrativa buscada para cada peça.

Assim, as instâncias de indeterminação (termo que reflete a perspectiva do compositor e sua atuação por meio de sugestões orais e da escrita) e jogo (termo que reflete a perspectiva de intérpretes e sua atuação em tempo real durante as performances) nos processos e produtos do Coletivo N.S.L.O dialogam com diferentes abordagens como parte dos esforços para a concretização de situações e roteiros constituintes das peças de nosso repertório. A indeterminação não ocorre como um fim em si mesma, mas como recurso criativo privilegiado para atingir objetivos expressivos específicos, particularizando a proposta estética e a experiência artística de suas criações.

Notamos ainda que os modos de organização de materiais musicais concebidos para delimitação de jogos nas performances passam a ser utilizados pelo compositor como recursos no planejamento de peças escritas de maneira tradicional, notadamente Rosa dos ventos. Este aspecto, pertinente à produção mais recente do grupo, será abordado em estudos posteriores. 


\section{Referências}

BORÉM, F. Lucípherez de Eduardo Bértola: a colaboração compositor-performer e a escrita idiomática para contrabaixo. Opus, Rio de Janeiro, v. 5, n. 5, p. 48-75, 1998.

BORÉM, F. Perfect partners: a performer-composer collaboration in Andersen Viana's Double bass Sonata. Double Bassist, London, n. 8, p. 18-21, 1999.

BOULEZ, Pierre. Troisième Sonate pour piano (1955-1957). Paavali Jumppanen. 1 vídeo (25 min). Publicado pelo canal meekojarvi. [S. l.: s. n.], 2014. Disponível em: https:// youtu.be/_99N6QudZx8. Acesso em: Jul. 2020.

CAGE, John. TV Köln (1958). New York: Henmar Press Inc., 1960. 1 partitura. Disponível em: http://exhibitions.nypl.org/johncage/node/244. Acesso em: Jul. 2020.

CAGE, John. TV Köln: Elif Önal (1958). Ankara: [s. n.], 22 nov. 2012. 1 vídeo (3 min). Publicado pelo canal Bilkent Composition, 2012. Disponível em: https://youtu.be/wWM30H5D4s. Acesso em: Jul. 2020.

CANONNE, Clément. Enseigner l'improvisation ? Entretien avec Alain Savouret. Tracés, Revue de Sciences humaines, v. 18, 2010. Disponível em: http://journals.openedition. org/traces/4626. Acesso em: Jul. 2020.

CARDASSI, L. Meu rosto mudou: time and place within a performer-composer collaboration. Sonic Ideas/Ideas Sonicas CMMAS, v. 4, n. 1, p. 31-38, 2011.

COSTA, R. L. M. Música errante: o jogo da improvisação livre. São Paulo: Perspectiva, 2016.

DOMENICI, C. L. O intérprete em colaboração com o compositor: uma pesquisa autoetnográfica. In: ENCONTRO ANUAL DA ASSOCIAÇÃO NACIONAL DE PESQUISA E PÓS-GRADUAÇÃO EM MÚSICA (ANPPOM), 20., 2010, Florianópolis. Anais [...]. Florianópolis: Anppom, 2010. p. 1142-1147.

DOMENICI, C. L. Beyond notation: the oral memory of Confini. In: PERFORMA, ENCONTROS DE INVESTIGAÇÃO EM PERFORMANCE, 5., 2011, Aveiro. Anais [...]. Aveiro: Universidade de Aveiro, 2011. p. 1-14.

DOMENICl, C. L. It takes two to tango: a prática colaborativa na música contemporânea. Revista do Conservatório de Música da UFPel, Pelotas, n. 6, p. 1-14, 2013. 
DONIN, Nicolas. Empirical and historical musicologies of compositional processes: towards a cross-fertilisation. In: COLLINS, Dave (ed.). The act of musical composition: studies in the creative process. Surrey: Ashgate, 2012. p. 1-26.

DONIN, Nicolas. Composer. Écritures musicales... sur le vif. Genesis, v. 31, 2010. Disponível em: http://journals.openedition.org/genesis/821. Acesso em: Jul. 2020.

FORTIN, Sylvie; GOSSELIN, Pierre. Considerações metodológicas para a pesquisa em arte no meio acadêmico. Art Research Journal, Brasil, v. 1, n. 1, p. 1-17, 2014.

GOMES, S. S. A reelaboração de passagens não idiomáticas do estudo n. 10 para violão solo de Marcelo Rauta por meio da colaboração intérprete-compositor. 2017. 134 f. Dissertação (Mestrado) - Universidade Federal do Rio Grande do Sul, Porto Alegre, 2017.

IDDON, Martin. John Cage and David Tudor: correspondence on interpretation and performance. Cambridge: Cambridge University Press, 2013.

ISHIZAKI, Y. B. M.; MACHADO, M. A. A colaboração entre compositor e intérprete no processo criativo de Arcontes. Revista do Conservatório de Música da UFPel, Pelotas, n. 6, p. 71-102, 2013.

KOELLREUTTER, H. J. Wu-li: um ensaio de música experimental. Estudos Avançados, São Paulo, v. 4, n. 10, 1990. Disponível em: http://www.scielo.br/scielo.php?script=sci_ arttext\&pid=S0103-40141990000300011. Acesso em: Mar. 2020.

MATHON, Geneviève. Poétiques de l'aléa. In: DONIN, Nicolas; FENEYROU, Laurent. Théories de la composition musicale au XXe siècle. Lyon: Symétrie, 2015. V. 2. p. 12131238.

LIMA, Paulo Costa. Composicionalidade: teoria e prática do compor no horizonte da atualidade. In: VOLPE, Maria Alice (ed.). Teoria, crítica e música na atualidade. Rio de Janeiro: Universidade Federal do Rio de Janeiro, Escola de Música, Programa de PósGraduação em Música, 2012. p. 117-132.

MORAES, Tharcísio V. Ludum, uma composição "jogo" - Técnicas de Áudio Dinâmico para Games aplicadas em outro contexto. In: SIMPÓSIO BRASILEIRO DE JOGOS E ENTRETENIMENTO DIGITAL (SBGAMES), 14., 2014, Teresina. Anais [...]. Teresina: SBGames 2015, 2014. p. 730-733.

NESRALA, Arthur. A improvisação como processo criativo: uma abordagem barroca e contemporânea. 2019. 93 f. Trabalho de Projeto de Mestrado - Instituto Politécnico de Castelo Branco, Castelo Branco, 2019. 
ÖSTERSJÖ, S. Shut up 'n' play! Negotiating the musical work. 2008. 409 f. Tese (Doutorado) - Malmö Academies of Performing Arts, Lund University, Malmö, 2008.

PUIG, D. Complexidade e metapadrões: composição com improvisação. In: CONGRESSO DA ASSOCIAÇÃO NACIONAL DE PESQUISA E PÓS-GRADUAÇÃO EM MÚSICA (ANPPOM), 23., 2013, Natal. Anais [...]. Natal: Anppom, 2013.

RADICCHI, J. M.; ASSIS, A. C. Inflexões para flauta solo: um estudo sobre a colaboração compositor-intérprete. In: CONGRESSO NACIONAL DA ASSOCIAÇÃO BRASILEIRA DE PERFORMANCE MUSICAL (ABRAPEM), 2., 2014, Vitória. Anais [...]. Vitória: Abrapem, 2014. V. 1. p. 202-210.

RAY, S. Breve reflexão sobre a performance da obra Movimento para contrabaixo e orquestra. In: ENCONTRO DA ASSOCIAÇÃO NACIONAL DE PESQUISA E PÓSGRADUAÇÃO EM MÚSICA (ANPPOM), 13., 2001, Belo Horizonte. Anais [...].Belo Horizonte: Anppom, 2001. V. 2. p. 523-530.

REBSTOCK, Matthias. Composed Theatre: mapping the field. In: REBSTOCK, Matthias; ROESNER, David (org.). Composed Theatre: aesthetics, practices, processes. Kindle Edition. Bristol, UK; Chicago, USA: Intellect, 2012a. Chapter 1.

REBSTOCK, Matthias. "Ça devient du théâtre, mais ça vient de la musique": the music theatre of Georges Aperghis. In: REBSTOCK, Matthias; ROESNER, David (org.). Composed Theatre: aesthetics, practices, processes. Kindle Edition. Bristol, UK; Chicago, USA: Intellect, 2012b. Chapter 11.

ROESNER, David. Introduction: Composed Theatre in context. In: REBSTOCK, Matthias; ROESNER, David. Composed Theatre: aesthetics, practices, processes. Kindle Edition. Bristol, UK; Chicago, USA: Intellect, 2012.

ROSA, A.; TOFFOLO, R. B. G. O resto no copo: colaboração compositor-intérprete. In: ENCONTRO ANUAL DA ASSOCIAÇÃO NACIONAL DE PESQUISA E PÓS-GRADUAÇÃO EM MÚSICA (ANPPOM), 21., 2011, Uberlândia. Anais [...]. Uberlândia: Anppom, 2011. V. 1. p. $1139-1144$.

SILVA, D. R. Processos criativos colaborativos na música contemporânea: dois estudos de caso. 2019. 378 f. Tese (Doutorado) - Universidade Federal do Rio Grande do Sul, Porto Alegre, 2019.

SILVA, D. R. A obra pianística de Marisa Rezende: processo de construção da performance através da interação entre intérprete e compositora. 2015. $191 \mathrm{f}$. Dissertação (Mestrado) - Universidade Federal do Rio Grande do Sul, Porto Alegre, 2015. 
STOCKHAUSEN, K. Aus den sieben Tagen (1968). Vienna: Universal Edition, 1968. 1 partitura. Disponível em: https://soundartarchive.net/articles/Lina_Lapelyte-2008-Aus. pdf. Acesso em: Jul. 2020.

TOKESHI, E.; COPPETTI, R. Técnica expandida para violino na música brasileira: um levantamento de material didático. In: SEMINÁRIO NACIONAL DE PESQUISA EM MÚSICA, 4., 2004, Goiânia. Anais [...]. Goiânia: PPG Música da UFG, 2004. 